bahasa \& sastra, Vol. 14, No.2, Oktober 2014

\title{
TRAVEL WRITING: AN APPLICATION OF WRITING WORKSHOP TO ENHANCE STUDENTS'S CREATIVE WRITING
}

\author{
Prayudias Margawati \\ English Department, Faculty of Languages and Arts \\ Kampus FBS Gd B3 UNNES Sekaran Gunung Pati Semarang 50229 \\ Ngablak RT 01/II no 412 Kenteng Nogosari Boyolali 57374 \\ E-mail: prayudias@gmail.com
}

\begin{abstract}
Writing is often assumed as uneasy skill to either learn or teach. For students, they find it difficult to develop ideas in writing. On the other hand, teachers, many of them, only ready with the materials but confuse with the appropriate ways to teach. This paper intends to describe and discuss a method of teaching writing namely writing workshop to improve students' writing skill through travel writing. Writing workshop proposed by Calkins that consists of mini lesson, work time, peer conferring and/or response groups, share sessions, and publication celebration is applied in writing class for methodological purposes. In mini lesson, teacher offers something to the class that is meant to introduce a writing strategy done at the beginning of the workshop. During work time point, students start their new piece of writing. Teacher moves among students conferring with them while checking their works. Peer conferences or response groups provide a forum for students to talk about works in progress. When students work in group, one of them could arrange his/ her group needs during the work time. A share session may be varied, one possible way is each group shares their process of writing to other students. At the end of writing class, student writers come together to publish and/ or celebrate their final work. The publication could be in the form of portfolio, students' diary, blog, or others. Travel writing genre is chosen as it could develop students' creativity in describing/ narrating their own stories during, let say holiday or things they used to see on the way home weekly or monthly. Furthermore, travel writing as the product of creative writing teaches the readers of values, characteristics, and way of life. Last but not least, a professional writing teacher should set the writing workshop components in variety ways to achieve effective running-class.
\end{abstract}

Keywords: Writing workshop, the components, creative writing, travel writing.

\begin{abstract}
Abstrak
Menulis kerap diasumsikan sebagai kemampuan yang tidak mudah untuk dipelajari maupun diajarkan. Bagi para mahasiswa, mereka sering menemui kesulitan mengembangkan ide dalam menulis. Di sisi lain, banyak pula dari para pengajar yang hanya siap dengan materi namun masih kesulitan menemukan metode yang tepat untuk digunakan dalam pengajaran mata kuliah menulis. Artikel ini bertujuan untuk menjelaskan sebuah metode pengajaran menulis yang disebut dengan writing workshop. Metode ini dimaksudkan untuk meningkatkan kemampuan menulis mahasiswa melalui genre travel writing. Writing workshop adalah sebuah metode yang digagas oleh Lucy McCormick Calkins dan terdiri dari lima (5) komponen; mini lesson, work time, peer conferring and/or response groups, share sessions, dan publication/ celebration. Dalam mini lesson, pengajar memperkenalkan strategi menulis di kelas yang dilaksanakan di awal proses belajar mengajar. Selama poin
\end{abstract}


work time, mahasiswa mulai melakukan proses menulis. Pengajar memeriksa pekerjaan mahasiswa satu persatu sambil mendiskusikan proses menulis mereka. Peer conferences atau response groups adalah sebuah forum bagi para mahasiswa untuk mendiskusikan pekerjaannya. Ketika mereka bekerja secara berkelompok, salah satu dari mereka dapat menyampaikan kebutuhan kelompoknya selama proses pembelajaran berlangsung. Komponen keempat yaitu share session dimana kelompok mahasiswa dapat berbagi pendapat tentang proses menulis mereka. Di akhir kelas, mahasiswa boleh mempublikasikan karyanya melalui media yang telah ditentukan oleh pengajarnya. Bentuk publikasi diantaranya adalah portfolio, students' diary, blog, dan lain-lain. Travel writing adalah genre yang dipilih untuk dapat meningkatkan kreatifitas dalam menggambarkan dan mendeskripsikan cerita pribadi mereka selama perjalanan seperti kunjungan atau momen liburan. Selain itu, travel writing sebagai produk dari penulisan kreatif dapat mengajarkan para pembacanya tentang nilai-nilai, karakteristik budaya, dan gaya hidup. Akhirnya, seorang pengajar writing yang profesional seharusnya menerapkan komponen-komponen writing workshop dengan model yang kreatif dalam menciptakan pembelajaran yang efektif.

Kata-kata kunci: Writing workshop, Komponen, Menulis kreatif, travel writing.

\section{INTRODUCTION}

Twenty five years after my father's return home to Nigeria, I arrive for the first time. I am optimistic though armed with little: a research fellowship, a few names, a binder of letters he wrote to my mother and me back in America when I was a child. I tell myself - and anyone who asks that no, I have not come to find him.... I'm hungry for heritage, yes. Siblings, perhaps. Schooling, the very thing my father out of colonial Africa for more than a decade is what calls me back. I plan to enroll at the University of Nigeria ... the junior brother explains my plan to spend a year learning "how to be Nigerian." (Adiele, 2007:269)

Dinner my first night in Kabul, however, was a revelation. We had spicy little meatballs in a rich sauce, a wonderful rice dish, crisp fried potato cakes, and delicious fresh Afghan bread. When I expressed astonishment, a friend explains that we had nabbed the best chef in Kabul, and that everyone who came to dinner at our house tried to poach him away. (Solomon, 2003:273).

... I've never had less of a plan in my life than I do upon arrival in Bali. In all my history of careless travels, this is the most carelessly i've ever landed anylace. I don't know where I'm going to live, I don't know what I'm going to do, I don't know what the exchange rate is, I don't know how to get a taxi at the airport - or even where to ask that taxi to take me. Nobody is expecting my arrival. I have no friends in Indonesia, or even friends-offriends. And here's the problem about traveling with an out-of-date guidebook, and then not reading it anyway. (Gilbert, 2006:225).

The quotations above are taken from Go Your Own Way, a compilation stories of women travel the world solo, The Best American Travel Writing, and Eat Pray Love, One Woman's Search for Everything. The paragraphs show how the authors write life experience during their trips through the story. The texts are simple to read although the writing activities is not a simple process. The 
process basically does not require complex requirements as it is a process of free writing which namely creative writing.

Technically, creative writing can be assumed as any writing of original composition. Specifically, the composition of creative writing tend to acquire needs like the need for keeping records of significant experience, sharing experience with interested group and for free individual expression. The purpose of this writing type is to express thoughts, feelings and emotions rather than to simply convey information.

Among some works under creative writing category, travel writing is one of popular genres which is quite unfamiliar in writing class. It typically records the experiences of the writer. It may be crosscultural or involve travel to different places within the country. This literature type is closely related to outdoor literature. Moreover, the genre often overlaps without definite boundaries. In line with that, Yudasmoro in Margawati defines travel writing as accounts of real or imaginary places that encompass a number of styles that may range from literary to journalistic (2013:367). An individual work of travel writing is sometimes called a travelogue.

Travelogue is usually composed by a writer who settles into a locality for an extended period, learning and observing sense of the place with his/ her sensibility. The trip becomes the occasion to study nation or people. In some bookstores or libraries in Europe or Asia, travelogue is commonly displayed as special genre. It is not included in either literary works or tourism category. Travelogue in Indonesia's most bookstores is classified in tourism section as it is similar to travel guide, a book which guides travelers to go on holiday or explore new places. The difference between the two is travel guide principally informs the description of tourism spots in certain places, while travelogue obviously narrates a coherent narrative of writer's experiences emotionally (Matatita, 2011:5). This genre involves writer's thought, impression and personal reflection toward the visited places.

Writing, as the central topic of this study, to some people is perceived as one of difficult skills among others. It is a complex process that needs basic knowledge in language such as vocabulary, structure and psycholinguistics. If scientific writing refers to obvious data and reference, literary works are based on imagination and creativity. To some degree, writing can be perceived as process of expressing idea. A long progress in writing basically requires creativity which then produces creative writing. The progress itself automatically requires purposes of writing. In line with that, there are purposes of writing suggested by Thompson (1996:28); (1) To talk about experience of the world, including the worlds in minds, to describe events and states and the entities involved in them, (2) To interact with other people, to establish and maintain relations with them, to influence their behavior, to express our own viewpoint on things in the world, and to elicit or change theirs., and (3) To organize messages in ways which indicate how they fit in with the other messages around them and with the wider context in which we are talking or writing.

In my writing class, most of my students often get difficulties to get, explore, and organize ideas on what they are supposed to write. Sometimes they say they know the topic of what they are going to write, but they (possibly we too as writing teachers) often get stuck and stop writing at the same time because of losing the ideas. "How can we always have ideas to express?" Brainstorming or free writing could probably help, however how we can write a draft if we do not know how to develop ideas. Astuti in her conceptual research (2007) wrote that there are types of writing teachers described by the 
students of writing class from the following quotations,

I can honestly say that I was never taught to write. I got more red-pen comments that any other students. Circles, cross-outs, underlines, and the worst one ever: the question mark. This didn't help my writing, it only bruised my ego. Not one teacher ever said to me: "This is what I want to see." They never showed me any example of good writing that I could learn from. I knew I couldn't write and I knew it, too. But nobody ever tried to change that. There was no such a thing as a first or second draft, only the final. I would just turn something in and hope for the best.

Now I work for a new teacher and he points out all the positives and helps me to improve the negatives. He shows me what I am already doing well and helps me learn how to fix my problems. I actually have a writing process, not just a piece of paper with million different ideas scattered everywhere.

Which type of writing teacher are you? From the testimony, it is clear that writing class students basically need sample writing, writing processes, feedback, words of encouragement, and also audience. Based on the situation above, this article intends to discuss and describe the application of writing workshop in enhancing students' writing skill through selected genre which requires visual and non visual imagination namely travel writing. Moreover, teaching writing class by applying writing workshop would hopefully help both students to improve their creative writing skills and teachers in developing their professionality in method usage in writing class.

\section{WRITING WORKSHOP COMPONENTS}

It is a method of writing instruction developed by Calkins (2006). The key to writing workshop is highly individualized instruction as well as a communal effort that encourages sharing between students or teacher and students. Writing workshop is designed for all grade levels, say, for all semester requiring writing classes. This method can accomodate students with an individual basis which allows them to learn at a developmentally appropriate rate (Waganan, 2008). With large amount of choice in topics and writing style, students are free to write their ideas or their own lives. Teachers, on the other hand, act as mentor author, modeling writing technique and conferring with students as they move through writing process. To support the process, Calkins (1994) suggests five components of writing workshop that can be arranged in a variety of different ways. The components are as follows:

\section{MINI-LESSONS}

Mostly teachers open the class with brief activity such as mini lesson. This activity may contain reviewing previous lesson or introduction to subject discussed for the day. The teacher might begin, say, "what did you do last weekend?" or "where did you go last week?" then he/ she will start narrating his/ her own activity during weekend. Another option for mini lesson activity is in 5 to 10 minutes, teacher reads a piece of experience of someone recorded in narrative story. Mini lesson is also possible for the teachers to introduce the topic of the day where students will spend more time in writing it. Another possible choice is that teacher or student offers something to class which intended to inspire or to instruct others. In relation to travel writing topic, the teacher may begin by saying: "I want to read something I promise would be nice ..." 


\section{WORK TIME (WRITING AND CONFERRING)}

Work time is requires the biggest amount of time for about 20 to 40 minutes. During the work time, students go to their desks and work on their ongoing projects. Students start to write their experience during, say, holiday or weekly visit to their hometown. The teacher may give them how to begin it, for example; ... This is exactly how I arrive in Jakarta. My plane landed in Soekarno Hatta airport around 2 pm. It was August 21. I find my luggage, then find a taxi that took me two hours to reach Bekasi where my family live there. I doze on the drive through the city, sometimes waking to look out the window, where I can see crowd of people walking alongside the road. Generally, the rule during the workshop is everyone writes. Teacher moves among individuals around the class to check the works. When teacher finishes with one piece, he/she moves on to another. Teachers may write alongside students for a few minutes of silent work time, then conferring with them. These conferences are at the heart of teaching process.

\section{PEER CONFERRING AND/OR RESPONSE GROUPS}

The response group frequently begins with the reports from each group represented by one member. The report might contain the process of students works, or one of them reports about the writing activities. Friends from other groups are free to response relevant comments. It is also possible to give suggestion toward the reported groups. Sometimes, groups will end with each member about the plan of what he or she will do in the next meeting. Calkins (1994) suggested that as writers, we need to be able to see what is almost there in a draft; we need to be able to see possibilities. We need to be able to imagine a draft written differently. People learn this special kind of reading by reading work in progress and talking about it. Peer conferences and response groups provide a forum for this. This component would take around 5 to 10 minutes. Peer conferences are usually student-initiated like five-minute-long talks about works in progress. Additionally response groups which usually consist of four to five members are usually formed by students at the teacher's suggestion.

\section{SHARE SESSIONS}

In 10 minutes of time allotment in writing workshop, share sessions generally begin after the entire class has gathered in one round group. The purpose of the session is to share and support work in progress. Share sessions function as public, teacher-supported conferences. The formats for a share session are varied. One example is the group shares their writing process, perhaps talking about how they feel about during silent writing time, or brainstorming together on what individual writers can do when they are stuck. These formats provide models for what students can do in their response groups and peer conferences.

\section{PUBLICATION AND CELEBRATIONS}

At certain time throughout the semester, students writers come together to try to publish and celebrate their finished work. Teachers should be creative in providing media to post the works. They might post in wall magazine, school magazine, or read by wider context of readers such as personal blog. However, teachers still have to work hard in reading students' works before they complete with editting conference or final revisions. For celebration, most teachers do different things for the component. They may invite other students from other classes into the classroom for one celebration, or make an audiotape of his or her best work. 


\section{APPLICATION OF WRITING WORKSHOP IN TRAVEL WRITING}

First of all, writing teachers need to have basic knowledge in this skill. Second of all, they should know methodologies in teaching writing. Third, they should have passion in both writing and teaching writing. How could they teach writing if they do not write themselves. To begin writing, a writer should read many books. Alwasilah in Astuti (2007) suggests that writing teachers must be writer themselves because a writer teacher does not only know how to teach but also has definitely first-hand experience in writing. Nonwriter teacher, on the other hand, tends to emphasize theories of writing because of their lack of empirical experience. In brief, teachers should encourage themselves and students to read more to produce pieces of literature.

Applying writing workshop method in travel writing will be mutually beneficial for both teacher and students. For teachers, they improve teaching writing skill by applying the method and learn students' perception about everything around as reflected from the works. For students, they are motivated and encouraged during the workshop through comments, corrections, suggestions from both teacher and peers. Furthermore, the products of travel writing from students will teach both parties about values, characteristics, way of life of the writers, either teachers or students. Finally, applying writing workshop in travel writing would ease the students in the process of writing creatively as they are inspired from mini lesson, given moment to express the feeling in work time, responsed from other peers, be opened in share session, and if they are lucky, their works will be published and read by a lot of readers.

\section{CONCLUSION}

Conclusion could be drawn from this study is that to teach a writing class, writing teachers should be creative in applying a method. When they focus on enhancing students' skill in writing, writing workshop is possible application to be applied in writing class. Through the components of the method designed by Calkins (mini lesson, work time, peer conferring, share sessions, and publication celebrations) that can be arranged in a variety of different ways, the process of learning in class will be more fun and attractive as students are fully involved in it. Teachers have an important roles to set the workshop itself.

Although writing workshop is definitely possible to be applied in any context of writing class, however, it is almost impossible to create an effective one if students write only once or twice a week. Students will find it hard to sustain an interest and remember what were they discussing last meeting. As Calkins illustrated, like any sport that if we jog once a week, it is hard to break the inertia brought on by six days of not jogging. But if we jog every day, it becomes easier and easier; we get into the rhythm, we find out stride. The same is true of writing (Calkins, 1994:188). Moreover, conducting writing workshop in class with more than 25 students would be also considered advantageous. Applying writing workshop in travel writing would give benefits for both parties, teachers and students. Teachers can improve their teaching skill with selected method, and students through motivations, encouragement and suggestion will expressively share their ideas in pieces of literature.

\section{ACKNOWLEDGEMENTS}

I wish to thank to people for their valuable technical support on this study. My deep gratitude goes to Matatita who has inspired me for her writings and her 
professional guidance in the workshop of travel writing in Ubud, Bali 2011 and Yogyakarta in 2012. My special thank also intended to Mrs. Rahayu who is working in travel writing as well for her knowledge, encouragement and useful critiques for my work. Finally I wish to thank to Puji Astuti for providing me valuable sources in completing the paper of writing workshop application in travel writing.

\section{REFERENCES}

Adiele, F. (2007). This Nigeris Will Eat You Up. Go On Your Own way; Women travel the World Solo. In F. Colon, I. Emerick and Christina. Pp $268-284$

Astuti, Puji. (2007). Analyzing the Needs of Undergraduate Student Writers of the Department of English Education of Semarang State University as a Means of Evaluating its Writing Curriculum. Unpublished Master's thesis. Indonesia University of Education Bandung.

Calkins, L. M. (1994). The Art of Teaching Writing. Ontario: Irwin Publishing.
Gilbert, E. (2006). Eat Pray Love; One Woman's Search for Everything. London: Bloomsburry.

Margawati, P. (2013). Travel Writing, When Travelers Meet Creative Writing. A Study of Travel Writing Works by Matatita and Trinity. Proceeding The Asian Conference on Arts and Culture 2013 Srinakharinwirot University Bangkok 13 - 14 Juni, hlm. 367-373

Matatita. (2011). Ubud Travel Writing Trip workshop handout. Yogyakarta: Bentang Pustaka

Solomon, A. (2003). My Dinner in Kabul; The Best American Travel Writing. In Frazier Ian. PP 272 - 275

Thompson, G. (1996). Introducing Functional Grammar. New York: Arnold.

Waganan, J. (2008). Teaching Writing with Writers Workshop: An Individualized Method to Teaching Students How to write. 